\title{
The Diamondiferous Behradih Kimberlite Pipe, Raipur District, Chhattisgarh, India
}

\author{
Datta Mainkar ${ }^{1}$, Bernd Lehmann ${ }^{2}$, Ray Burgess ${ }^{3}$ and Boris Belyatsky ${ }^{4}$ \\ ${ }^{1}$ Directorate of Geology and Mining, Sonakha Bhavan, Ring Road 1, Raipur 492006, Chhattisgarh, \\ India;datta_mainkar2002@yahoo.co.uk \\ ${ }^{2}$ Institute of Mineralogy and Mineral Resources, Technical University of Clausthal, 38678 Clausthal- \\ Zellerfeld, Germany; Lehmann@min.tu-clausthal.de \\ ${ }^{3}$ School of Earth, Atmospheric and Environmental Sciences, University of Manchester, Manchester M13 \\ 9PL,UK; ray.burgess@manchester.ac.uk \\ ${ }^{4}$ Institute for Precambrian Geology and Geochronology, Russian Academy of Sciences, St Petersburg \\ 191014,Russia; bbelyatsky@mail.ru
}

The occurence of eluvial diamonds on the Bastar craton in Central India was first reported in the early 1990s from Payalikhand village in the southeastern part of Raipur district, Chhattisgarh. Investigations of the Geological Survey of India (GSI) and the Directorate of Geology and Mining (DGM) led to discovery of the Behradih and Payalikhand kimberlite pipe, followed by other pipes in the surroundings of the Kodomali and Jangda villages. This kimberlite cluster is now known as Mainpur Kimberlite Field (MKF) (Mainkar et al., 1998).

Later investigations led to discovery of kimberlitic bodies in the Temple and Kosambura area (Oropa, 2000). So far, the kimberlitic bodies at Payalikhand, Behradih, Kodomali and Temple are confirmed as diamond-bearing diatreme-facies kimberlites. The pipes are located within a zone of about $16 \times 5 \mathrm{~km}$ extending in northwesterly direction (Fig. 1).

\begin{abstract}
The Mainpur Kimberlite Field is located close to the faulted contact of the Bastar craton and the Proterozoic Eastern Ghat Mobile Belt (EGMB), between longitudes $82^{\circ} 10^{\prime} \mathrm{E}$ to $82^{\circ} 25^{\prime} \mathrm{E}$ and latitudes $20^{\circ} 08^{\prime} \mathrm{N}$ to $20^{\circ} 15^{\prime} \mathrm{N}$. The kimberlite pipes are emplaced within the Bundeli granitoids of Archaean to Early Proterozoic age. These meta-granitoids include porphyritic, gray coloured granites and equigranular biotite granite. The granites are locally affected by pervasive propylitic overprint (chlorite-epidote-carbonate). Epidotized granites are forming low mounds within highly dissected topography developed by the Bundeli granitoids. Very coarse-grained biotite granite with epidote veinlets is the host rock to the Behradih and Temple kimberlites. Gabbroic and doleritic dykes are forming swarms in en-echelon pattern trending northwest and cutting the Bundeli granitoids.
\end{abstract}

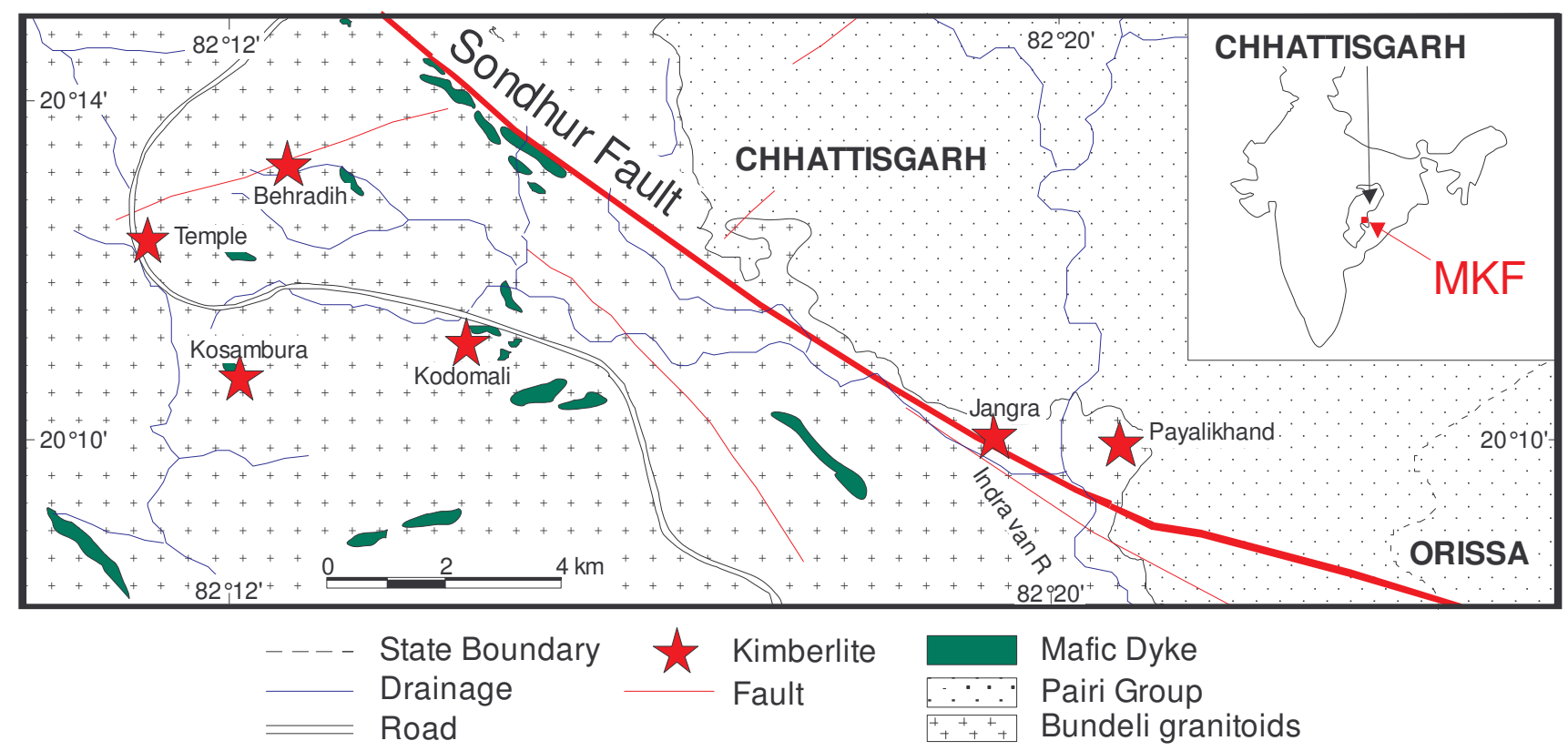

Fig. 1. Geological map of Mainpur Kimberlite Field 
These are parallel to the regional Sondhur fault and associated secondary faults. Younger aplite granites occur in a WSW-ENE trend, almost parallel to the regional Garhchiroli fault. The kimberlites are located close to the Meso- to Neo-proterozoic sedimentary sequences of the Pairi Group (GSI, 2006) to the east, which unconformably overlie the ArcheanPaleoproterozoic basement and form the Kariar highlands.

The Payalikhand and Jangda kimberlites are located very close northeast of the Sondhur fault, while the Behradih, Kodomali, Temple and Kosambura pipes are in the southwestern block a few $\mathrm{km}$ away from the main Sondhur fault (Fig. 1).

The petrography and geochemistry of the poorly diamondiferous Kodomali body has been described by Fareeduddin et al. (2006). The Kodomali pipe was dated by Ar-Ar as of Early Paleozoic age (Rao et al., 2007). A Phanerozoic age is also suggested by its $\mathrm{Nd}$ isotope composition (Lehmann et al. 2006). This is different from most other kimberlites in India which have an age around $1100 \mathrm{Ma}$ age.

\section{Sample material}

All known kimberlite bodies in the MKF are deeply weathered with several m thick "green earth" soil at the surface, a smectite-rich clay. The only exception is the Kodomali pipe which stands out in very fresh outcrops.

The diamondiferous Behradih pipe has a diameter of about $200 \mathrm{~m}$, with no outcrops of hard rock. The pipe was drilled by the Directorate of Geology and Mining (DGM) (Singh et al., 2000) in five boreholes down to up to $188 \mathrm{~m}$ depth. Petrography and geochemistry have been studied on selected drillcore samples of the Behradih kimberlite and are summarized here.

\section{Petrography}

The drill core of the Behradih kimberlite is variably weathered and altered. The rock is dark greyish to greenish, with inequigranular porphyritic texture, consisting of macrocrystic pseudomorphed olivine of rounded habit, along-with phlogopite, xenocrysts of pyrope and mantle and crustal xenoliths set in finegrained groundmass.

Pseudomorphed olivine macrocrysts (up to $6 \mathrm{~mm}$ ) are mostly preserving their original habit. Phlogopite macrocrystic laths are seen densely packed in a few samples. Phlogopite microphenocrysts are common, both of tabular habit and as poikilitic aggregates in olivine, with varying shades from pale brown to green. Pelletal lapilli of pseudomorphed olivine and autolith ranging in size $1 \mathrm{~mm}$ to $15 \mathrm{~mm}$ are set in the groundmass. In a few samples, pelletal lapilli with olivine core surrounded by fine-grained groundmass matrix are seen. Microphenocrystal diopside is common. Crustal xenoliths of varying dimensions and irregular shape include gabbro, granite, shale and sandstone. Rare, brownish to dark red pyrope xenocrysts are strongly resorbed and also occur as rounded inclusions in pelletal lapilli.
The groundmass consists of fine grained mineral grains of phlogopite, clinopyroxenes (diopside) and opaque minerals. Glassy groundmass is also observed in some samples. Accessory phases include perovskite $(<0.025$ $\mathrm{mm}$ ), chromite, spinel, magneitite, titanite, zircon, apatite and pyrite (Mainkar and Lehmann, 2007). A characteristic feature of the rock is the presence of segregations consisting of relatively coarse-grained euhedral crystals of mica and clinopyroxene that project into chlorite matrix.

\section{Geochemistry}

The major element composition of 35 bulk-rock samples was analyzed by XRF at the Federal Geological Survey of Germany. $\mathrm{SiO}_{2}$ content is 42.3 $\pm 0.8 \mathrm{wt} \%$, and $\mathrm{MgO}$ content is $23.2 \pm 1.4 \mathrm{wt} \%$ confirming that the rock is ultramafic in nature. Other major oxide compositions are $1.04 \pm 0.11 \mathrm{wt} \% \mathrm{TiO}_{2}$, $4.8 \pm 0.5$ wt $\% \quad \mathrm{Al}_{2} \mathrm{O}_{3}, 7.1 \pm 0.5$ wt $\% \quad \sum \mathrm{Fe}_{2} \mathrm{O}_{3}, 5.1 \pm 0.8$ $\mathrm{wt} \% \mathrm{CaO}$. Loss on ignition is $12.3 \pm 2.5 \mathrm{wt} \%$ (gravimetric). The alkali contents are $0.74 \pm 0.14 \mathrm{wt} \%$ $\mathrm{Na}_{2} \mathrm{O}$ and $1.9 \pm 0.6$ wt $\% \quad \mathrm{~K}_{2} \mathrm{O}$, confirming the ultrapotassic nature of the rock. Diagnostic trace element data obtained from XRF techniques are 1180 $\pm 150 \mathrm{ppm} \mathrm{Cr}$ and $1000 \pm 120 \mathrm{ppm} \mathrm{Ni}$. The niobium contents are $96 \pm 16$ ppm, strontium $818 \pm 126$ ppm and zirconium $208 \pm 24 \mathrm{ppm}$. There is a wide variation in barium contents from 980 to $~ 8000$ ppm, with most Ba in least weathered rocks.

A second set of sample splits was analyzed by XRF at Ultra Trace Analytical Laboratories, Perth, WA. Average major oxide whole rock analysis for these samples $(\mathrm{n}=10)$ yielded $44.3 \mathrm{wt} \% \mathrm{SiO}_{2}, 1.15 \mathrm{wt} \%$ $\mathrm{TiO}_{2}, 5.27$ wt $\% \mathrm{Al}_{2} \mathrm{O}_{3}, 7.62$ wt $\% \mathrm{Fe}_{2} \mathrm{O}_{3}, 23.8$ wt $\%$ $\mathrm{MgO}, 5.95$ wt $\% \mathrm{CaO}, 0.78 \mathrm{wt} \% \mathrm{Na}_{2} \mathrm{O}$ and 2.39 wt $\%$ $\mathrm{K}_{2} \mathrm{O}$, which corresponds to the major element drill core sample analysis.

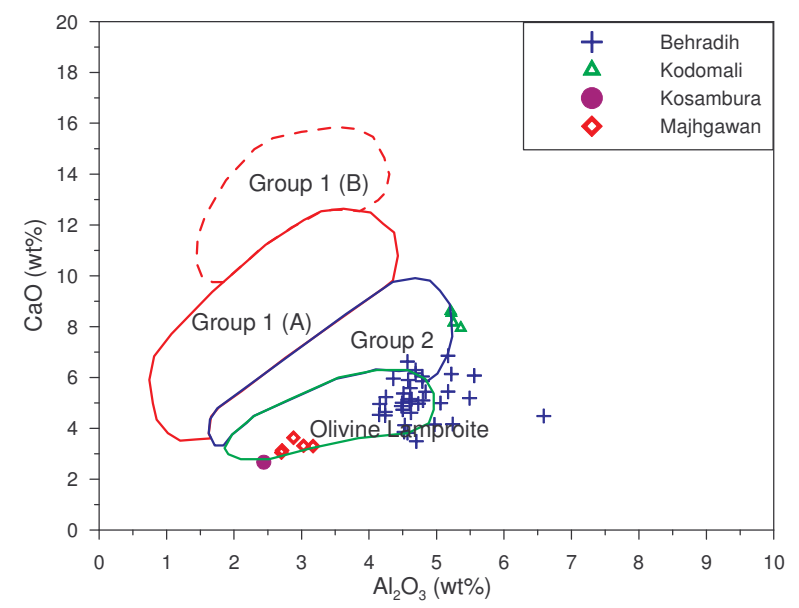

Fig. 2. $\mathrm{CaO}$ vs $\mathrm{Al}_{2} \mathrm{O}_{3}$ variation diagram . Reference fields in this and the following plots from Taylor et al. (1994).

The Contamination Index (CI) of the Behradih samples is $1.9 \pm 0.1$, suggesting minor contamination. The $\mathrm{Mg \#}$ is $86.6 \pm 0.7$ and corresponds to rocks of deep mantle origin. 
Rare Earth Element (REE) and selected trace element analysis was carried out via ICP-MS. The chondrite normalized REE plot of the drill core samples indicates strong LREE enrichment with $\mathrm{La} / \mathrm{Lu}$ around 500.

The $\mathrm{CaO}$ vs $\mathrm{Al}_{2} \mathrm{O}_{3}$ variation plot (Fig. 2) indicates that the Behradih samples are close to the compositional fields of South African Group-II kimberlite and olivine lamproite, with some extension towards more elevated alumina contents, probably due to contamination. The diagram also includes some samples from the Kodomali and Kosambura pipes, both from MKF, as well as five reference samples from the Majhgawan pipe, a $\sim 1100 \mathrm{Ma}$ lamproite in Central India with active diamond mining.

The $\mathrm{TiO}_{2}$ vs $\mathrm{K}_{2} \mathrm{O}$ plot shows the distinct difference of the MKF samples compared to the Proterozoic Majhgawan pipe which has elevated titanium content. The Behradih pipe depicts a large variation range in potassium, related to variable amounts of phlogopite, and the compositional field overlaps distinctly with the South African Group-I and Group-II kimberlite fields, but does not correspond to olivine lamproite (Fig. 3).

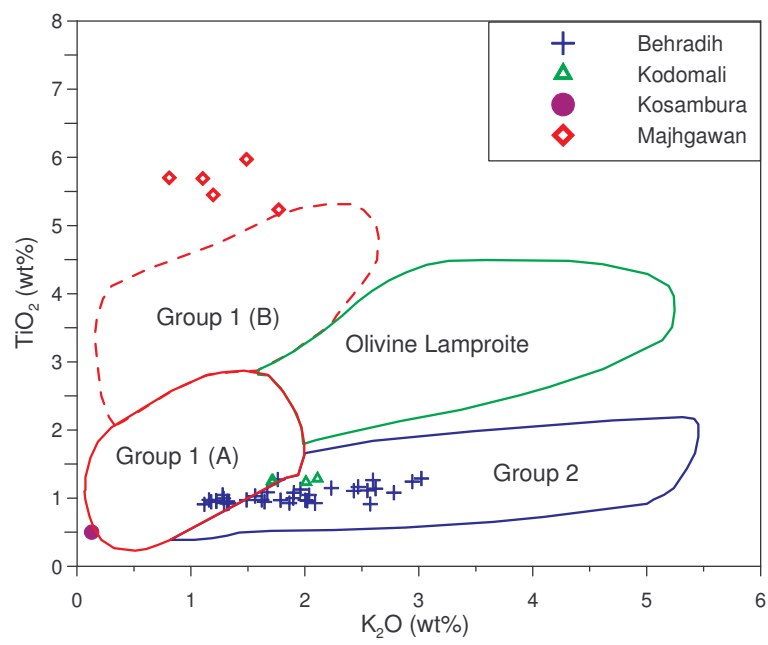

Fig. $3 \mathrm{TiO}_{2}$ vs $\mathrm{K}_{2} \mathrm{O}$ variation diagram with kimberlite and lamproite reference fields

The above petrogenetic interpretations are supported by the low niobium and zirconium abundances in the samples from Behradih, Kodomali and Kosambura, which are distinctly different from the Majhgawan lamproite (Fig. 4). The MKF samples plot at the overlapping confines of the South African Group-I and Group-II kimberlite fields.

The affinity of the Behradih samples with Goup-II kimberlites is further corroborated by $\mathrm{Sr}-\mathrm{Nd}$ isotope data on six bulk-rock samples. The initial ${ }^{87} \mathrm{Sr} /{ }^{86} \mathrm{Sr}$ isotope composition is $0.70837 \pm 0.00093$, and the $\varepsilon \mathrm{Nd}$ value is $-6.4 \pm 1.7$.

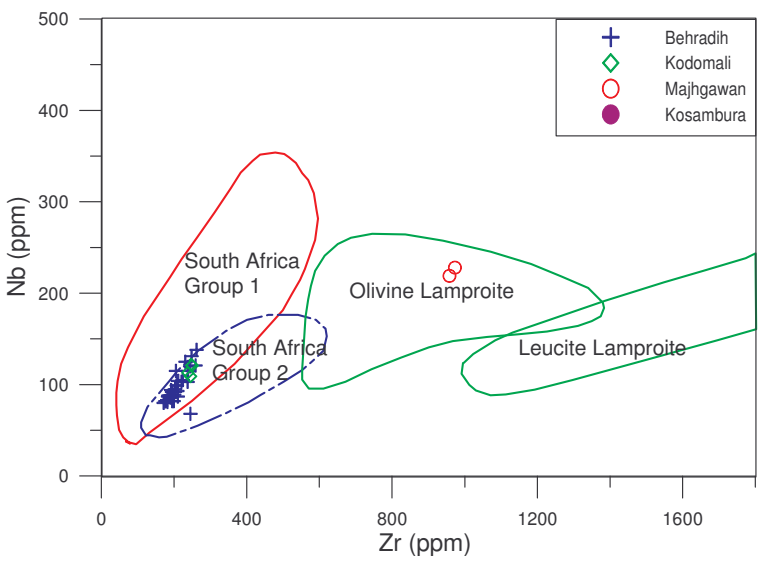

Fig. $4 \mathrm{Nb}$ vs $\mathrm{Zr}$ variation diagram

In summary, the geochemical and isotopic data suggest that the Behradih and Kodomali kimberlitic rocks be defined as Group-II kimberlites.

\section{References}

Fareeduddin, Pant, N.C., Neogi, S.. 2006. Petrology of Kodomali kimberlite, Mainpur kimberlite field, Chhattisgarh. Implications for a Palaeozoic orangeite field. Journal of the Geological Society of India, 68, 19-34.

GSI, 2006. Geology and Mineral Resources of Chhattisgarh, Geological Survey of India, Misc. Publ. No. 30, Part XXI, $2^{\text {nd }}$ Revised Edi., 60 pp.

Lehmann, B., Mainkar, D., Belyatsky, B., 2006. The Tokapal Crater-facie kimberlite system, Chhattisgarh, India: Reconnaissance petrography and geochemistry. Journal of the Geological Society of India, 68, 9-18.

Mainkar, D.; Kankane, S.; Singh, H.P.; Pashine, J.K., Jain V.K. 1998. Tokapal kimberlite field: Tectonic, Lithological Control and Tokapal kimberlite, $24^{\text {th }}$ AEG Annual Convention, Proceed. Vol. Editor, S.K. Varma: 184-204 pp.

Mainkar, D., Lehmann, B., 2007). The Diamondiferous Behradih Kimberlite Pipe, Mainpur Kimberlite Field, Chhattisgarh, India: Reconnaissance Petrography and Geochemistry. Journal of the Geological Society of India, 69, 547-552.

Oropa, 2000. Announcement 25th July 2000; Block D-7, M.P., Macro and micro diamonds rocovered from orientation samples collected from first pass sampling, http://www.oropa.com.au.

Rao, N.V.C., Burgess, R., Anand, M., Mainkar, D., 2007. ${ }^{40} \mathrm{Ar}^{39} \mathrm{Ar}$ dating of the Kodomali Pipe, Bastar Craton, India: A Pan-African (491 \pm 11 Ma) age of diamondiferous kimberlite emplacement. Journal of the Geological Society of India, 69, 539-546.

Singh, S.B., Chandrakar, N.K., Verma, D., Saxena, V., 2000. Report on the prospecting for diamond in BehradihKodomali area, district Raipur (M.P.) F.S. 1996-98 Directorate of Geology and Mining, Unpubl. Rept.

Taylor, W.R., Tompkins, L.A., Haggerty, S.E., 1994. Comparative geochemistry of western African kimberlites: evidence for a micaceous kimberlite endmember of sublithospheric origin. Geochimica et Cosmochimica Acta, 58, 4017-4037. 